\title{
Trade Unions and Decentralized Production: A Sketch of Strategic Problems in the West German Labor Movement
}

\author{
HORST KERN AND CHARLES F. SABEL
}

In the last decade liberal or social-democratic observers in the United States and Great Britain have been increasingly drawn to the dual German system of industrial relations as a way of protecting the interests of employees at the company level, encouraging the continuous reorganization of firms required by current competitive conditions, and yet collectively defending the economic and political interests of those who live from paychecks, regardless of where they are employed. The dual system, in a word, holds out the promise that the efficiency advantages of the Japanese company union can be reconciled with the social-democratic conviction that democracy in advanced capitalist countries requires the participation of a national labor movement.

Seen this way the dual system is indeed attractive. In the typical mediumsized or large firm in the private sector, a works' council is elected every three years by all permanent employees, unionized or not, according to a formula that assures blue- and white-collar workers representation proportional to their numbers in the company. The chief power and distinguishing feature of the factory council is its de facto capacity to force management to elaborate

Funding for the research on which this essay is based was provided by the International Institute for Labor Studies of the International Labor Organization. The views expressed, however, reflect only the opinions of the authors. An earlier version of the paper was published under the title, "Gewerkschaften in offenen Arbeitsmärkten. Überlegungen zur Rolle der Gewerkschaften in der industriellen Reorganisation," Soziale Welt 41, no. 2 , (1990): 144-160. This essay appears in Labor Movements Toward the Year 2000, Marino Regini, ed. (New York: Sage, 1991). 
comprehensive "reconciliation of interests" (Interessenausgleiche) in the event of any consequential change in the company, including, for example, a major sale of assets or the introduction of new technologies. American unions defend employees' rights piecemeal, and often with little possibility of assessing the competitive effects of their actions, by elaborating and then bargaining the redrawing of rules governing the definition of jobs, eligibility for promotion, and seniority rights. The works' council, in contrast, uses its ability to influence the substantive outcome of reorganization to reach encompassing agreements with management that do justice to the rights of the work force while respecting the constraints of competitive conditions. At a minimum, the obligation to negotiate reorganization reduces the danger that management will jeopardize the possibility of long-term survival by abrupt efforts to restore profitability in the short-term through reduction of labor costs. At a maximum, the works' council system creates a bargaining regime in which, as in Japan, both parties almost reflexively prefer high-wage, high-skill solutions to adjustment problems as both efficient and just.

Outside the plant, as in the United States, but unlike Japan, the dual system provides a well-articulated structure of collective bargaining. Bargaining is by industry and region, with agreements in each industry typically governed by the pattern set in a key regional contract. General rules governing, for example, working time, training programs, or the type of wage determination system in an industry, are renegotiated at irregular intervals. Wages are renegotiated annually. This bargaining regime is complemented at the bottom by firm- or plant-level agreements that extend the minima established in the regional contracts, and by extensive, often legislatively mandated participation in the institutions that make and execute labor-market social-welfare, and even health-care policy. In this sense the German labor movement is an advocate for the collective and changing interests of the little people or the average Joe and Jane in a way that Japanese company unions, at least as they have usually been understood in the West, are not.

The firm-level and extra-firm elements of the dual system are linked in at least three ways. First, the vast majority of works' councillors are active trade union members, and depend on the unions' support in their campaigns for election. Second, the most prominent works' councillors in a region sit on the union commissions that establish the collective bargaining demands, and many hold unpaid but influential positions in the union bureaucracy. Third, representatives of the national or regional union may serve together with factory councillors as members of a firm's advisory board (Aufsichtsrat). Besides approving major investment plans, the chief responsibility of the Aufsichtsrat—often regarded as the core of West German labor-management co-determination or Mitbestimmung - is to elect the managing directors of the firm, and through them influence 
choice of its chief operation officers. Labor's rights to representation on a particular supervisors board vary according to the size and sector of activity of the corresponding company and are regulated by a body of legislation whose extraordinary complexity is a constant reminder of the bitter conflicts provoked by every effort to extend those rights. In the best case, labor can always be outvoted by a united management; but even in the worst, labor acquires supplemental information about managerial plans and additional possibilities for coordinating its own response.'

The dual system's theoretical appeal is reinforced by the apparent stability of the trade unions in the Federal Republic of Germany despite more than a decade of the kind of industrial reorganization that has shaken labor movements in countries as diverse as Sweden, Italy, and the United States. One indicator is the slight increase in the average percentage of the total work force organized in trade unions. ${ }^{2}$ Another is the unions' willingness to initiate provocative debates concerning many of the problems with which they are confronted. These include the reduction of work time, the use of new technologies, the reduction of environmental risks, and the recruiting of workers with the kinds of skills and ambitions demanded for success in the most rapidly growing parts of the highly competitive export economy.

But under this unblemished surface, there are forces at work that could create a completely different picture. A closer look at the statistics shows that the trade unions' membership is less and less representative of the work force as a whole. A coarse but serviceable generalization is that the distribution of trade-union members by occupation and skill level today resembles the distribution of jobs and skills characteristic of the workforce about 30 years ago. An obvious danger signal is the labor movement's growing difficulty in recruiting young workers. In 1970, 23.2 percent of employees in the metal working industries under 25 years of age were trade union members. In 1987, the corresponding figure had sunk to 17.5 percent. ${ }^{3}$

Likewise, the debates, as stimulating as they may be when taken one by one, appear less promising upon closer examination. Not that each has been a flash in the pan. But each has been conducted in isolation from the others, and organized in such a way as to reinforce rather than reduce bureaucratic specialization of the unions' organization. Thus, "work time" is a problem for specialists in collective bargaining; "chips" was the responsibility of the experts in technology policy; "recruiting problems" was subsumed under the rubric of policies toward white collar workers, whereas "ecology" went under the rubric of "relations to others" - that is, to the state, to the political parties, and to the social movements.

What has been missing is a general concept for reorganizing the trade unions that suggests a coordinated attack on the individual problems. The disorientation which local trade union activists manifest in almost every conversation reflects 
the lack of such a general concept. Uncertain of their members' support, and convinced that the national unions' leadership misunderstands or simply ignores them, many factory councilors in the metal working industry seize the powers to intervene in restructuring that they have by law, or which management has thrust upon them as a last, desperate chance to secure their local position. If, as frequently happens, union officials in the distant national headquarters later tell them that their decisions violate the spirit or even the letter of collective bargaining agreements, they feel more isolated than before-and more convinced than ever that there is no comprehensive union strategy to guide their decisions. Such experiences are paralyzing. Above all, they make it still more difficult to recruit new members and mobilize existing ones. A vicious circle begins, and the anxious, fitful talk of a trade union crisis that has filled the pauses in the open discussion of recent years suddenly becomes more than just chit-chat.

The following essay is a first effort to connect some of the isolated pieces of this debate. In the next section, we briefly discuss some of the most important trends in the reorganization of industry. Our central thesis is that as the boundaries between the corporation and its environment-other firms and society in general-become more permeable, labor markets are becoming open in unexpected ways. The third section discusses the problems which trade unions face as labor markets open, and section four examines some potential trade-union responses to these dilemmas. These form the core of the essay. The central argument here is that the same logic of industrial reorganization which is undermining the trade unions' current organization also creates the possibility for a fundamental reformulation of their strategies. We sketch the general conditions under which a reformulation could occur, and we elaborate discussion of these enabling conditions with examples drawn from the unions' current activities. But we do not consider such plainly important questions as how company reorganization has effected macroeconomic policy making in Germany, or the unions' possible response to these changes. First things first.

Our investigations are based primarily on research that we conducted in German automobile manufacturing companies and their suppliers. With regard to the car manufacturers, we interviewed experts in three firms in the areas of production, technology planning, logistics, and purchasing. In addition, we spoke with representatives of the works' council. The interviews were complimented in all cases by extensive factory visits. We conducted interviews in 15 supplier firms. They were selected because of their central position in the relevant markets. The interviews with the suppliers were less extensive than those with the car companies, though this was, in part, simply a result of the formers' more compact organization. The interviews were conducted in January, July, and August 1989, together with Gary Herrigel. Knowledge of other similar investigations in the United States, Italy and Sweden formed a backdrop for the study. 
The central body of research on which this essay is based, finally, was concluded before the fall of the Communist government in the German Democratic Republic (GDR) and the subsequent incorporation of the GDR into the Federal Republic. We do not offer an account here, therefore, of the specific and enormous problems that the collapse of the economy of the former GDR and the current efforts to restructure it on competitive lines pose for the German trade unions. But the temporal and territorial limitations of our research do not, we are convinced, undermine the urgency of the following arguments. Whatever the latest developments in East Germany may eventually mean for the German trade unions, several preliminary conversations with trade unionists in the new Länder in August-September, 1991 make one thing certain: these developments will not free the unions from the dilemmas of industrial reorganization traced below. On the contrary, there are already signs that reunification is stultifying within the unions even the hesitant and sometimes contradictory debate about strategy noted a moment ago. The wage earners in the former GDR lack both a language and the institutions for political self expression; they are all too accustomed to entrust resolution of everyday problems to bureaucratic agencies. It is no wonder that they are by all accounts delegating to the trade unions full responsibility for protecting their jobs, or, failing that, negotiating severance settlements by taking full advantage of the Federal Republic's complex labor law. These tasks are grist for the mills of the unions' traditionalists, who suddenly find a humanly compelling justification for their view of the labor movement as the advocate of the wage earners' rights at the workplace. And those trade unionists in the new Länder who would ardently participate in the new debates are simply crushed by traditional administrative responsibilities. One way or another, these preoccupations are likely to make the troubling developments to which we now turn more explosive still.

\section{THE OPENING OF THE FIRMS AND THE REGIONALIZATION OF PRODUCTION}

The framework for trade union action is being redefined by fundamental changes in industrial structure. The substance and scope of these changes is itself a vast subject. ${ }^{4}$ For present purposes, it is enough to underscore two general tendencies which we regard as decisive for the future of trade union development.

The first concerns the growing diversification of product markets. In stable markets, it pays end producers to vertically integrate. By so doing, they can protect their know-how, appropriate most of the value added in manufacturing, and guarantee regular provision of key components of the final product. This was, of course, the classic strategy of mass producers from the time of Henry Ford until the first oil shock of 1973 . Since then, many markets have become much 
more turbulent. Under the growing pressure of competition, augmented by producers from developing countries, firms in the advanced industrial economies have increasingly begun to manufacture products tailored to the precise wants of consumers who are both willing and able to pay a substantial price premium for goods which correspond more exactly to their expectations. By adopting this new product strategy, the firms accelerated the very differentiation of demand to which they were reacting. Markets became more and more fluid. Even successful products can be sold in only relatively small volumes. Product innovation is becoming ever more important, which means that the costs of product development are increasing. Today, even the most powerful of the large corporations are often unsure which technologies will finally prove to be important for new products, to say nothing of their uncertainty about which variant of all the possible production technologies will prove to be most appropriate. Reducing development costs and time, while increasing innovative capacity-these are the new imperatives.

In order to do justice to these constraints, many firms or operating units are simultaneously reconceptualizing both product and production strategies. This reconceptualization depends on, among other things, referring the relation between internal development and external suppliers. Complex products are increasingly conceptualized as systems of subsystems or modules. Instead of developing each subsystem itself, the final producer defines the characteristics of the product as a whole, and the functional relations between the different modules of which it is composed. Whenever possible, each of these is then developed in collaboration with a system supplier who possesses the relevant technical expertise and know-how. Final assembly, however, remains the responsibility of the final producer. ${ }^{5}$ This collaboration with systems suppliers makes it possible to promote innovation without provoking an explosion of the cost and time of development. The suppliers' advantages in their special areas of technical expertise become more generally available - the more so because supplier firms with customers in different industries can bring the results of one research effort to problems which arise in the others. For this and other reasons, development costs are more broadly distributed; basic designs are diffused more rapidly within and across industries. In short, there is a redefinition of the relation between firms and, at the least, an erosion of the traditional boundaries between them.

This trend reinforces and is reinforced by new developments in the factories themselves. Above all, it is the introduction of the different variants of flexible automation and the increasing network of different technical and organizational units which encourages the reconceptualization of product and process. Managers today no longer hesitate to group several of their internal units into networks. External suppliers may be included in the same kinds of systems. The introduction of just-in-time delivery systems is becoming commonplace-a sign of how 
rapidly this process of integration is advancing. ${ }^{6}$ In principle, every step in the production process, from development to distribution, is regarded as a variable whose effects on all of the others can be measured and regulated. This expansive integration does not, however, eliminate the need for highly skilled human intervention in the production process. Although it may be, in principle, possible to regulate the relation of each subunit to all of the others by technical means, it would be in fact unbearably expensive to do so. Network systems turn out to be a paying proposition only when experimentation and improvisation have indicated when and under what conditions particular units can be connected with others. Such (empirical) experiences influence the definition of the machine operators' skills. Increasingly, these skills tend to include complex combinations of traditional craft knowledge and more general theoretical training.

The second tendency follows from the first. The logic of specialization and diversification, which underlies the firms' response to increasingly differentiated markets, also leads to the formation or sharper definition of regional economies: clusters of firms or operating units with different, typically complementary specialties, which collaborate to serve common markets. ${ }^{7}$

The more fluid markets become, the riskier it is to hold or produce for inventory. Hence the attractiveness of just-in-time delivery systems. These require, of course, that suppliers locate their production or warehouse facilities in the proximity of their customers' assembly works, or at least develop transportation capacities which assure a kind of virtual presence. Likewise, the more fluid the markets, the less time there is to develop and evaluate new technologies. The more probable it is, therefore, that face-to-face contact of employees of different firms will be necessary to accelerate the exchange of knowledge. In this way, knowledge becomes local knowledge, fully comprehensible only to those who participate in the day-to-day exchanges in which it is articulated. Once firms have learned to profit from such coordination or come to think that they might, they are determined to maintain or establish a substantial presence in the geographic area in which this expertise is grounded. Call this the localization effect of firms - or of members of a community of producers - on each other.

The more specialized firms become, finally, the more each depends on the collective provision of services which none can provide for itself. Examples are training, research, hazardous waste disposal, supplemental unemployment or medical protection, environmental monitoring, market information or warehousing. Many of these services can be supplied by private vendors. But in any particular case, some are almost certain to be provided by local authorities or in partnership with them. As firms come to rely on collective and especially public provision of crucial services, however, they become part of the local community. 
Their survival depends on its prosperity. Call this the localization effect of providing exoskeleton to specialized firms.

Although the regionalization of production is a direct consequence of the other responses to market fragmentation, the foregoing does not require that all of the key operations needed to manufacture a complex product be located in a single region. Some must be, for reasons having to do with just-in-time logistics and collaboration in the development of particular technologies. But a company often finds it easier to collaborate with a supplier located in a distant network than to try to establish a local producer of a key subassembly. Hence, regionalization and internationalization of production may proceed hand-in-hand; the more robust the local economy, the more it attracts and is attracted to complementary foreign localities. The decisive point is that, independent of the precise distribution of activities among regions, the reintegration of conception and execution leads to patterns of production specialization through which firms in a particular area become tied to one another and to the use of services whose provision depends on the continuing prosperity of a particular locale.

\section{SMALL STEPS TO RADICAL CHANGE}

The actual process of reorganization of large firms is, of course, more piecemeal, and proceeds much less purposefully and peacefully than this sketch of textbook adjustment suggests. Radical change is often the result of a long chain of responses to a few initial decisions taken at best in the spirit of the architecture of the new system.

A few of these chain reactions are particularly common, and two drawn from the automobile industry will do to illustrate the drift of decision making. Take first the case which results in an increase in subcontracting, but the savings achieved through out-sourcing are offset by the increased costs of administering the more complex supplier system. The obvious answer is to reduce the number of suppliers by making the most competent of them responsible for combining discreet components into subassemblies or modules. It is natural to give these suppliers authority to improve the subassemblies, provided they still meet the original specifications. But no doubt there will be some highly beneficial modifications which require a (slight) revision of the original design. The customer begins to accept these as well and the example is infectious. If the process goes far enough, the design engineers begin to conceive of the car as a system of systems, each of which might be manufactured by an independent producer.

Alternatively, take the case of car companies that look to new supplier relations for help in mastering new technologies with origins outside the auto industry. Subassemblies based on engineering plastics or microelectronics are 
obvious examples. But here too there is no stopping point. Microelectronics can be, and in some more expensive cars already are, used to control the operation of the engine, the brakes, the suspension, and-through the use of control area networks which make information generated in each such system available to the others-the relation among them. Who is the car manufacturer if all complex systems in the car and even the links among them are designed in substantial measure by suppliers?

High-level managers at companies as diverse as Volkswagen, Mercedes-Benz, FIAT, Ford and BMW are well aware of the sources of drift, and in most cases uncertain of what to make of them. One common, provisional response is to simultaneously note and limit the increased collaboration with suppliers by distinguishing systems (such as the motor and power train) which the company must make if it is to retain its competitive identity and advantage, and those it can make, but might subcontract to suppliers with independent design capacities. But if we asked two or more managers seated at the same table whether a particular subassembly might soon be reclassed from "must" to "can," they frequently disagreed and said that their differences would be resolved by a committee whose very purpose was to settle such disputes. In principle, they typically added, anything could be designed and produced outside. But final product aside, what defines the identity of and gives internal structure to a car company which may not find it opportune to design fully of manufacture any particular part of a car, even the most important?

\section{ADJUSTMENT IN SMALL FIRMS}

To better grasp the logic of the current reorganization and take the measure of the confusion with which it is proceeding, it is convenient to examine the process briefly from the point of view of the small and medium-sized firms which it affects. The suppliers' response to the pressures and uncertainties they face depends on their current position. Many of the largest, who are also typically those with the greatest capacity for research and development, are restructuring to become systems suppliers. Sometimes this involves merger of two previously independent companies, as when a manufacturer of wire seat frames and position controls merges with a manufacturer of upholstery to form a company which can build sophisticated seat modules in plants close to automobile assemblers. In other cases restructuring means the expansion and concentration in one location of research capacity in, for example, air-conditioning or cooling systems, and the construction of new, highly automated green-field production facilities-reconcentrating in the process some previously subcontracted operations in order to insure quality and steady supplies of parts. (Whether, after a period of consolidation, these firms might not follow the example of their large customers, 
subcontract some production steps, and reintegrate conception and execution by decentralizing research capacity to the new production facilities is another question.)

Smaller firms are in a much weaker position. Often they must simply accept their large customers' "recommendations" for the introduction of new technology or inventory systems as a precondition for the renewal of current contracts. They may have to submit to inspection of their production process and quality and control techniques as well. Production schedules may have to be synchronized with the customer's, and changed on demand. All of these forced-draft accommodations may in the end actually increase the firm's capacity to diversify its business and thus reduce its dependence on its current clients, but there is no guarantee that they will. ${ }^{8}$

\section{RESTRUCTURING AS AN OPPORTUNITY AND DANGER FOR THE UNIONS}

There is, we see, a pattern to the industrial reorganization, but nothing like a harmoniously agreed common strategy to realize it. Power struggles in the large firms reverberate with power struggles in the small- and medium-sized ones. There is as much confusion as consensus, sometimes as much cynicism as confidence about the feasibility of strategic plans. And all this-the changes themselves, the confusion, the confidence, and the cynicism-undermine the organizational foundations of the union in the firm while creating possibilities for new ways of defending and expanding wage-earners rights.

In the Federal Republic, the current reorganization of industry creates new possibilities for the exercise and extension of trade-union authority simply because German codetermination laws allow labor to block or delay many of the changes management wants. Whether it is a question of more flexible use of labor, including corresponding changes in the regulation of the legal work-week and overtime; lengthening the permissible periods of production, including relaxation of restrictions on shift and weekend work; greater freedom to rejuvenate the workforce, including increased use of early pensions to remove older workers and more aggressive hiring of younger persons with up-to-date technical skills; extensive retraining and continuing education programs-the factory council's approval is required for the execution of any of these measures. Where fundamental questions of company policy are raised, labor's representatives on the Aufsichtsrat can demand a more deliberate hearing under the codetermination laws. And quite apart from all their legally secured influence, the trade unions have countless opportunities to intervene in the process of restructuring simply because consensus, however minimal, is almost always the precondition for change. German management is aware that it cannot wage a 
two-front war against its competitors and its work force. From this perspective, serious conflicts with factory councilors who make disruptive use of their codetermination rights or even mobilize those workplaces still well enough organized to stand the strain are simply too dangerous to risk. The managers we spoke to know that their careers depend on the outcome of projects whose success would be jeopardized by protracted conflict. They are convinced that change by fiat does not work. They are ready to bargain.

At the same time it is clear that the day-to-day decisions shaped by the current logic of industrial reorganization work to undermine the unions' positions on the shop floor and in the corporation as a whole. Three problems stand out; and unless the unions discover a way to use their bargaining power to address them in a concerted way, they may cumulatively transform the de facto rules of collective bargaining in Germany.

First, industrial reorganization is leading to increasing demand for more technically skilled employees whom the unions have great difficulty organizing. To begin with, the firms are increasingly recruiting university trained engineers. In Germany, this group has never had an affinity for the labor movement. Perhaps more important, however, are the changes in the career patterns of evening-class (graduierte) engineers. Traditionally this group was formed by skilled workers who spent several years full-time on the shop floor upon completion of their apprenticeship, and then enrolled in evening courses to finish their education. Apprenticeship and shop-floor experience inclined them to union membership; and they typically remained loyal to their origins even when promoted to influential management positions. Today, however, there is less time to form loyalties to labor because the young skilled workers are abbreviating their stints on the shop floor and continuing their education almost immediately after completing their initial training. The expectation that they will do so, moreover, casts a shadow back onto their experience of apprenticeship, which is now often seen less as an induction into a world of craft work than as a practical phase in an educational sequence that ends far from the shop floor. To make matters more complex, it is precisely these younger, technically skilled workers and eveningschool engineers who tend to participate in the ad-hoc project groups which so often create an implicit labor-management counterelite in the firm by their capacity to solve problems which baffle older, more centrally placed managers and factory councilors. In the late 1960s, West German sociologists of work were concerned that the night-school engineers, a crucial link between management and the shop-floor, would be displaced by university-trained professionals with indispensable technical expertise, but ignorant or mistrustful of the craft versatility on which the flexibility of so many firms depended. Two decades later it seems more unlikely than ever that the evening-class engineers will be pushed aside or their ties with the shop floor broken. The question today is whether the 
very success of that group and the strengthening of those ties does not for the first time weaken rather than reinforce the union's role in the plant.

The question is all the more pressing because the traditional union goals are not these groups' most pressing concerns. Collectively bargained wage increases, protection from the intensification of work, formal recognition of skill, and legal reinforcement of job security are of secondary interest to persons who in virtue of their knowledge have a strong position in the labor market and who, so long as they are young, are unlikely to want to work where they are unwanted. Their chief concerns lie elsewhere, in areas where the unions until now have had little to say: in the opacity of the firm's decision-making process and hierarchy; in the scanty opportunities to influence directly crucial decisions; in confusion about how they themselves are to keep pace with technical change; and, most generally, in worries about the long-term unpredictably of their own careers. Nor are these the problems of a small elite. Multiskilled maintenance workers, highly trained systems operators with responsibility for millions of dollars of equipment and quality-control personnel whose responsibilities increasingly overlap with those of the industrial engineer all have concerns which increasingly resemble those of the engineers-the more so, the younger they are. Thus industrial reorganization increases the number of those unlikely to grow into a world of which the union is a natural part, while reducing the number of those who will. ${ }^{9}$

The recruitment problems which these structural changes cause for the union are aggravated by concomitant changes in the typology and geographic distribution of production units. So long as research, marketing, and production were carried out in one complex, the trade unions could use their organizational strength in the last area to win members and exert influence in the first two. But to the extent that large suppliers, for example, even temporarily isolate production in greenfield sites away from other corporate activities this connection is broken. Stripped of contact with production, the labor bastions in large industrial centers could become centers of company or yellow unionism, while the new, peripherally located production centers might remain beyond the reach of a labor movement which tends to be skeptical that smaller firms and workers with little industrial tradition can be organized in the first place-not to mention the additional problems of addressing workers in foreign subsidiaries.

Second, there is the problem of the unions' fundamental organizational unit: the company, and, since the installation of industrial unionism, the branch, understood as a collection of firms working similar materials, using similar production technologies, and making related products. In the heyday of mass production the giant firms in the centers of heavy industry and the heavy industries themselves were the central units of trade union organization. But the more open the boundaries among firms and branches become, the less relevant these units can be as points of orientation of trade union strategy. The decentral- 
ization of production within a given firm means, for example, that manufacturing operations previously executed in one place are now dispersed to sites in many different trade union jurisdictions; and the problems of coordinating policy with a greater and greater number of increasingly autonomous plant managers, allied, perhaps, with local union barons, are correspondingly more complex. When local managers make company policy, what good is the union's influence on corporate headquarters?

Increased subcontracting, especially when it concerns collaboration in the development of new products or technologies, obviously multiplies the unions' organizational dilemma. A product previously manufactured by operating units all within the jurisdiction of, say, IG Metall, suddenly becomes an assembly of subassemblies produced by firms within the jurisdiction of, among others, the chemical and textile workers. Insofar as these activities are drawn together by regionalization, they potentially form the basis of new organizational entities. But the concentration on firms and branches, we will see, has left the unions ill equipped to make use of even those few existing structures which might be adapted to the formulation of regional policies cutting across traditional industrial jurisdictions.

Third, although the factory councilors are better trained, better protected by law, and better supported by expert staffs than they were in the 1960s, their capacity for action is simply inadequate to the demands of the situation. Try as they will, they simply cannot address, let alone solve, all the questions which reorganization simultaneously poses. The best indication of their limits is the proliferation in the plants of informal, expert "advisory groups" whose purpose is to assist the factory councils in formulating policy on specific, technically complex questions. Such groups (which may well be anchored in the project teams discussed earlier) are so common that they are discussed as a quasi-official institution in the trade unions' own publications, although no attempt is made to clarify their relation to the legally constituted organs of employee representation. ${ }^{10}$ Under these conditions, it is natural enough for factory councilors to set priorities and dedicate their full energies to the crucial problems. But even this apparently straightforward ambition is almost unattainable because industrial restructuring introduces a systematic tension between factory councilors' longand short-term goals. In the short term, it seems morally obligatory and politically expedient to defend the interests of groups such as poorly paid, semi-skilled women, elderly workers, or the partially handicapped which are threatened most directly by the early rounds of decentralization. The temptation to take up defensive positions here is all the greater given that the union can likely find powerful allies among those managers whose own position also is or soon could be threatened by subcontracting to systems suppliers. 
But this is a strategy which at best produces pyrrhic victories. The more successful the union is in blocking incremental change in marginal areas, the more likely management is to delegate complex, risky development projects to systems suppliers with a freer hand. If the experiments succeed, the manufacturing operations to which they give rise are likely to remain there where they were developed-beyond the immediate jurisdiction of the factory councilors, and perhaps, in the case of collaboration with a foreign firm-beyond the reach of the German labor movement as a whole. To continue with the automobile example: for the moment, determined defense secures in-house production of seat modules, but the development and production of automotive electronics and new plastics prospers beyond the horizon of the factory council. Worse still, insofar as defense of the least skilled means defense of the standardized operations which are most vulnerable to low-wage competition, short-term success increases the plant's and the union's long-term vulnerability; and the effort to increase employment security actually undermines it.

A few years ago, West German observers were warning that, absent a powerful national union able to discipline local activity through broad collectivebargaining agreements, inevitable alliances between factory councils and their respective plants managements would lead to the rapid spread of company unionism. In the light of the reorganization of the corporation that warning is beginning to sound like a forlorn and perverse hope.

\section{THE REORIENTATION OF TRADE-UNION STRATEGY}

To our knowledge, there is no comprehensive answer, theoretical or practical, to the dilemmas of trade-union strategy just discussed. The theoretical answers are flawed by their assumption that unions must learn to control flexibility within closed organizations. The promising practical solutions are incipient and fragmentary - and despite their promise, they may not work. Nonetheless, it is these experiences, in combination with the preceding analysis, which orient the following efforts to deepen our understanding of the current trade-union disorientation by trying to imagine a way to address it.

First a conclusion which is just dawning on German unions, but which has become, through bitter experience, the starting point of a new generation of U.S. trade-union organizers: it is futile to hope that the conflicts inevitably provoked by industrial reorganization, and involving engineers as well as production workers, will of themselves drive employees into the unions. West German firms, sometimes influenced by U.S. examples, are experimenting with various forms of "union-free" employee-representation plans which have thus far proven effective at neutralizing potential conflicts, if nothing else. Trade unions and factory councils will be able to turn conflicts to their own organizational 
advantage when they can offer responses to attacks on employees' interests which are both plausible and feasible: plausible, in that they secure acceptable redress for individual or group grievances, and feasible, in that they encourage the firm to behave in ways which reinforce its economic vitality, and hence increases its capacity to make subsequent concessions. Our discussion of the unions' strategic possibilities is framed by these constraints.

Our point of departure is the effect of industrial reorganization on the very constitution of the labor market. An understanding of the complex, apparently contradictory consequences of corporate decentralization and regional agglomeration is, we believe, indispensable to the formulation of any trade-union strategy whose aim is to turn the new competitive conditions to labor's advantage. We begin by sketching responses which address the needs of highly skilled workers-the traditional core of the unions' constituency in the Federal Republic, and the reservoir from which most of its leaders at all levels have been drawn. Then we will try to show that the same strategy which appeals to them can be further developed to meet the concerns of the un- and semi-skilled.

The analysis of the preceding sections describes a double paradox. First, the modern corporation needs a highly skilled core workforce, yet it itself has (almost) no institutional core in which this workforce can be guaranteed secure employment. The whole effort to reintegrate conception and execution depends on the cooperation of skilled persons in sales, design, manufacturing, on the one hand, and in the systems suppliers, on the other-all with an intimate, almost instinctive knowledge of the corporation's needs. But the openness of the corporate boundary to the outside world, especially the constantly shifting but more intimate relation to subcontractors (the systems suppliers) and consultants (the former staffs reconstituted as independent firms, or complete outsiders operating on the open market) make it impossible to say which activities will go on inside the firm and which outside. When the status of whole production or research units can change in a matter of months, or at least when everyone knows that such changes are always possible in principle, production workers, technicians and engineers must always wonder about how they will survive if they are on the job market.

In particular, they must always be thinking about how to acquire skills in their present position which will equip them for employment if they have to leave it. And they must realize that this is not easy to do within the confines of their current work unit. The smaller and more specialized production units become, the less likely they are to be able to offer in-house the kind of broad, fundamental training at all levels which equips people to meet the challenges of new situations. Broad training programs, whether organized by large corporations or public institutions, make matters worse. They underscore the limiting particularity 
of the employee's current situation simply by drawing attention to the whole range of crucial developments with which he or she has no direct experience.

Second, work in the restructured economy simultaneously increases and limits employees' autonomy in the world of life outside it. The experience of the new corporation increases the possibilities of individual self-expression outside the firm. This is not primarily a result of an increase in the amount of or control over leisure time or an increase in disposable income. Rather, the sense of autonomy and self-respect developed at work seems to bolster employees' self-confidence outside of work. " Employees who are encouraged to think of themselves as entrepreneurs and to treat dealings within their own firm as market transactions are being forced to manage resources and risks in ways which make it easier to imagine changing the conditions of one's life in many regards. The prospects of going into business for oneself, or simply taking a job in another company, are likely to look less forbidding. Chemical workers who have been instructed about hazardous materials they handle on the job provide another, more surprising example: they are much less tolerant of environmental threats at home than workers without equivalent experiences. ${ }^{12}$

But this enhanced autonomy-which can, as the last example suggests, become a source of challenges to the most various and deep-seated assumptions about social life-is simultaneously qualified by the same situation which produced it. Just as the firms must form networks with one another and their environment in order to keep abreast of local knowledge, so too must individuals secure their long-term employability through participation in social networks outside the firm. "Private" associations-hobby and self-help groups, clubs, neighborhood associations, single-issue groups, or political parties-are today seldom institutional expressions of a coherent, all-encompassing group life defined by class position, political persuasion or religious faith. Typically, they are associations of sociable but "individualized" persons, whose sociability outside the firm often gives rise to, and may be shaped by, connections that reach not so much into any particular workplace as into the world where they work. And increasingly, as the ecological example again suggests, the nominally private and nominally economic spheres of activity are both connected to the world of politics and public institutions.

These private social networks, therefore, amount to early warning and coordination systems which neither public nor private job-placement agencies can provide. Only persons who participate in multiple, loosely connected networks are likely to know when their current jobs are in danger, where new opportunities lie, and what skills are required to seize them. The more open corporate labor markets become, the greater the burden these networks will have to bear, and the greater the economic compulsion to participate in the social activities they organize. 
This tendency may well be reinforced by the reconstitution of domestic life, which, of course, is influenced by, but hardly reducible to the reorganization of work. The growing labor-force participation of women, part cause and part effect of changing gender roles, is creating an increasing number of two-earner households. For such households, with their double dependence on the local labor market, participation in community life-day-care centers, schools, neighborhood improvement associations-is often a precondition of participation in paid employment.

This is not to suggest that domestic life becomes a mere appendage of economic activity, as it may have almost become during some periods of industrial production. Rather, open labor markets of the kind we are describing depend for their operation on networks which function on the condition that they do not mirror the current pattern of economic activity too closely. If they did, they plainly would not help individuals and firms reassemble under new conditions. Seen this way, however, the networks-and with them the part of life which is considered private (from the point of view of the firm) and social (from the point of view of the family) - become part of the public exoskeleton which firms depend on in their constant efforts of reorganization.

From this it follows that the distinction between a person's interests as an employee and his or her encompassing interest in well-being is becoming so blurred as to be unrecognizable. If unions intend to address the interests of their members and potential members, therefore, they must be at least as attentive to regulating the relation between work places and between work places and living spaces as they have been to regulating the conditions of work in firms and sectors. Continuing education programs; job counseling and placement; planning in the sense of help in finding or creating the institutions needed to integrate domestic and work life - all of these are examples of services directed toward this new field of regulation. Failure to provide them or some equivalent would be for the unions to forego the possibility of organizing - pun intended - just those experiences which characterize "modern" employees, and condemn them to representing a social world which is shrinking even as its boundaries become indistinct.

Indeed, to push the point to its logical conclusion and underscore its connection to the analysis of industrial structure, the union in an open labor market would in this view assume responsibility for provision of skilled labor-a requirement of production which management can no longer organize by itself. In doing so, the union would become in its way a systems supplier. There are already tendencies in this direction in the Federal Republic, particularly as a result of the unions' participation in the organization of vocational training and the administration of labor-market programs. 
Were the unions to assume this role, it would not entail their subordination to the companies. Firms, we saw, collaborate with systems suppliers because they have to, not because they want to. For companies, the price of the cooperation they need is a new and consistently renegotiable dependence on outsiders who can do things the firms can no longer (afford to) do for themselves. Why should firms' relations to union systems suppliers be less ambivalent? There is historical precedent for the claim that they would indeed not be. In the early days of the craft unions, which were frequently socialist, the provision of skilled labor under regulated conditions to specialized firms was a key source of labor's power on the labor market in general, and within firms as well. Naturally, the unions cannot return to the nineteenth century. But, given the direction of industrial reorganization, it is hard to see why control of conditions outside the firm could not become a new source of trade union strength.

What makes the pursuit of such a strategy especially complex is that services that correspond to novel definitions of interest are often already available, but in a partial and intractable form designed to advance other ends under the current system of interest representation. Reorienting union strategy along the lines we are suggesting requires reconstructing existing institutions as much as building new ones from scratch. Discussion of the possibilities of and obstacles to the use of continuing education as a cornerstone in a new system of trade-union representation will illustrate both the general intent of our programmatic argument and the kinds of institutional considerations which bear on its realization.

\section{CONTINUING EDUCATION AS AN EXAMPLE OF NEW TRADE UNION STRATEGY}

Neither an initial period of formal education, however long, nor constant adjustment to changing conditions through learning by doing today guarantees a person's long-term employability in the reorganized economy, let alone secures a particular job. The more open the corporations and the labor market, the more important become the capacity for systematic (re)education and the willingness to participate in it. Unions can play a double role in the organization of continuing education. On the one hand, they can help employees understand the importance of further training and how to obtain it. On the other, they can monitor their education to insure that the skills provided are so systematic, certifiable, affordable and remunerative that they do indeed increase the employees' chances of prospering not just at a particular job, but on the open labor market.

The situation in the Federal Republic, a country widely admired for its comprehensive educational system, clearly demonstrates the need for this supervision. To be sure, the firms clearly recognize the need for continuing 
education as a concomitant of restructuring. Expenditures per employee for such training doubled between 1981 and $1985 .{ }^{13}$ But it is equally clear that many firms understand continuing education as the provision of just those supplemental skills required for a particular job; ${ }^{14}$ that they are not concerned with the general development of employees' craft or professional qualifications except at the very highest level $;{ }^{15}$ and that to the extent they can, they define the need for continuing education as a risk to be born by the employee as an individual.

Here the unions have organizational motives for acting as a corrective. To the extent that they are seen as guaranteeing their members and indeed the workforce as a whole the kind of systematic and well-rounded training which can quickly be put to use in diverse work settings, they acquire both a broad constituency and a place in the institutional order. In theory at least, the firms themselves have an interest that they do so.

This is because individual firms pursuing a strategy of profit maximization through specialization have little incentive to design programs of continuing education that do justice to the breadth and variability of their own long-term needs. The flexibility requirements of the open labor markets are often at odds with the cumulative results of the firms' short-term planning strategies, although firms need not be aware of the potential disparity. The limits of the firms' capacities in this regard are evident in the fact that in several of the suppliers we visited, the factory councilors had already assumed responsibility for assessing both short- and long-term training needs of each and every employee. Under these conditions, the unions' efforts to correct the narrowness of the firms' plans (or, more accurately, expedients and vague projections) contributes to the exoskeleton of institutions upon which the collective success of restructuring efforts depends. Naturally this convergence in principle of trade union and firm interests shapes company behavior no more directly than a theoretical account of the advantages of the new subcontracting systems changes the behavior of purchasing agents. Complex and often unpredictable causal chains, we saw, connect current patterns of behavior to the realization of such models, if they are realized at all.

A recent survey of trade-union policy in this area suggests, moreover, that the labor movement in the Federal Republic is far from making the most of whatever opportunities to influence these developments it already has. ${ }^{16}$ Take, for example, the factory councilors, the de facto though not de jure representatives of the union in the plant. Under sections 90, 92, 96, 97, and 98 of the Betriebsverfassungsgesetz, they undeniably have substantial powers to influence the organization and provision of continuing education, however controversial the interpretation of their precise rights in particular matters may be. But as a rule, the study shows, little is made of this potential influence. The factory councilors do not generally appreciate the general growing significance of continuing 
education; and if they do, they are ignorant of their rights to influence it. ${ }^{17}$ Exceptions of course prove the rule. The same study reports the experience of some factory councils in machine-tool and auto-supplier firms - as well as in one major auto producer in the midst of a wide-ranging reorganization-which managed to correct the "job-specific character of plant-level continuing education measures, and to embed them in a larger context of work reorganization." ${ }^{18}$ Our own discussions with union officials and factory councilors corroborate these findings. Although it might appear that unions have a natural interest in encouraging and generalizing such initiatives, it is only in the last years that the metalworkers union has begun to make continuing education a central theme of collective bargaining.

The first regional agreement with relevant provisions was concluded in 1987 and 1988 between IG Metall and the entire metalworking industry in BadenWürttemberg (LGRTV I); in the same period a related agreement was reached between the union and Volkswagen. The contracts oblige employers to periodically assess their expected training needs and to discuss these with the factory council. On the basis of this assessment, training programs are to be designed with the concurrence of the factory council. Training is to take place during normal working hours, and those who complete the planned courses are to be assigned work which requires use of their new skills, or paid as though they were performing this more demanding work. To date there has been no evaluation of the effects of either the obligation to plan training or to pay the successful trainees at rates corresponding to their certified skill level. ${ }^{19}$ But there is good reason to think that these agreements are only the beginning of a broader effort at regulation which could systematize and extend many informal measures in a way which might indeed establish the union as an indispensable interlocutor in questions of further training, if not a system supplier of skilled labor.

\section{FROM THE OUTSIDE IN AND AROUND: CONTROL AS A SOURCE OF INFLUENCE WITHIN FIRMS AND THE REGIONAL ECONOMY}

Control over local labor markets shades into and requires increasing participation in the formulation of corporate strategy on the one hand and regional economic policy on the other. To stay with the preceding example: in order to judge which kinds of continuing education will be required, it is necessary to know the firm's investment plans. That is the minimal form of the required participation. At a maximum, joint efforts to define training needs would blur into efforts to reach agreement about all the aspects of product strategy, citing decisions, and personnel planning which bear on the long-term prospects of job security. Although this maximalist program may seem to hopelessly overstate the unions' possibilities of influencing company behavior, there are well known 
instances at Volkswagen and other important firms where elements of this kind of joint decision making are already practiced in the Federal Republic.

Where this is the case, the collaboration is the expression of a broader and often deliberate-though not formal-modernization pact between the factory council and management. The latter guarantees job security for all current employees, indemnifies them for losses sustained as a result of reorganization, and obliges itself to give as many employees as possible a chance to advance into whatever higher skilled jobs may be created. In return, the former agrees not merely to tolerate reorganization, but to foster it by helping to bring the expertise of the workforce to bear wherever needed. The "advisory groups" mentioned earlier are often called into being or at least openly recognized for this purpose. $^{20}$

This kind of cooperation plainly makes both sides uneasy. In discussion, manager often wonder about what "rights" they may be trading away in exchange for the workforce's "constructive" participation. Trade unionists worry that such participation in managerial activities will (or appear to) compromise their autonomy and political identity. We spoke with one trade-union official in Baden-Württemberg, who was particularly sensitive to the ambiguities of the situation, perhaps because he had entered the labor movement as a result of his experiences during the student protests of the late 1960s. To advance Labor's interests through the new form of collaboration, he said, it was necessary to "worry yourself to death with the other guys' problems." He defined his own participation in such compromises ironically as "social partnership from the Left"- a formulation that expresses the unionists' persistent fear that the cooperation will end in cooptation, perhaps even loss of the capacity to strike against the firm. For the moment, both parties to these cooperative arrangements seem as aware of the need to retain the power to withdraw from them as the need to make them work.

Simultaneously, however, the exercise of control over open labor markets requires the local union to extend the radius of its action to the region as a whole. As local firms come to depend more and more on one another and on the exoskeleton of locally provided services, the union in any single plant can often best protect the long-term employability of its members by working with firms and trade associations, as well as municipal, regional, or federal authorities, to encourage the establishment or growth of companies or production units crucial to the integrity of the regional economy. This amounts in part to a kind of forward defense against the decentralization of production and development to suppliers outside the region. A more important aim, however, is to diversify the local economy, rendering it less vulnerable to shifts in demand and better able to regenerate itself should there be a dramatic deterioration of any of its key markets. ${ }^{21}$ 
To pursue these kinds of strategies, unions will have to adjust their own structures. Here the unions might take a page from the corporations' book on the decentralization of responsibility and the opening of institutional borders. In order to provide the new labor-market services and influence the strategies of both firms and public authorities, they must move beyond their jurisdictional limits to create local, grass-roots alliances among themselves and with many actors they have ignored or battled in the past: municipalities, nonprofit groups, social movements, political parties, churches, and educational institutions. The result would be "networking of trade-union capacities." 22 To do this they will need the authorization of national unions, whose authority will also be necessary to institutionalize successful regional experiments.

Many recent commentaries sponsored in one way or another by the labor movement in the Federal Republic and often published in its journals in fact emphasize the need to reinvigorate local unions and increase their capacity to act regionally by strengthening their ties to other local groups. ${ }^{23}$ Differences in particulars aside, these commentaries concur on a crucial point: they regard "horizontal" networking as a subsidiary complement to traditional trade-union activity. The common argument is that groups at the margin of the production process or threatened by expulsion from it-"housewives, retirees, apprentices, the unemployed, college and high school students" 24 can be won for the unions through "the incarnation of union projects in local work." 25 The emphasis is, therefore, on organizing defensive activities which demonstrate the unions' capacity to prevent plant closures or, more generally, loss of local jobs, as well as to counter attacks on the local provision of welfare benefits. (J. Hoffman and Läpple as well as v. Gleich, however, also argue for a more offensive strategy closer to the one presented here.)

Important as they are, from our perspective, these activities miss the strategically decisive point. Corporations, we argued, are experimenting with new governance structures in which headquarters attempts to retain the coordinating authority of last resort, while decentralizing substantial, potentially self-reinforcing autonomy to operating units, and through them to systems suppliers. At the same time, these new governance structures create open labor markets that blur the distinction between jobs inside and outside the corporation, as well as the distinction between paid work and social life. By organizing the open labor markets and shaping regional economies, the unions can influence the new governance structures - not least by encouraging those aspects of decentralization which augment their own capacity to gain further influence. On this view, they ought not aim to exemplify labor's collective power locally, but rather to redefine the very substance of that power - the relation between labor and capital-by changing the extent and goals of local action. Thus understood, localization of union strategy goes hand in hand with its universalization, and is a precondition 
for that "broadening of the trade union mandate" so often mentioned in the German labor movement's current strategic discussions.

The instruments of such a union strategy, moreover do not need to be developed from scratch. Clues about what institutional solutions might work are buried in the historical experiences of the trade union confederation's regional councils (the DGB-Kreise and Ortskartelle). In the immediate postwar years these played a significant role in some regions, only to decline into insignificance during the heyday of the large, centralized corporation. ${ }^{26}$

These could be reactivated and redirected in the light of a comprehensive reorientation of union strategy. ${ }^{27}$ But if we are right, it will only be possible to revitalize these institutions if their networking is seen not as a marginal complement to current policies, but as a central part of the unions' effort to turn the new industrial structures to their advantage by shaping-through a kind of determinedly self-assured collaboration-their very formation.

\section{THE UN- AND SEMI-SKILLED}

The same analysis of industrial reorganization which suggests a new union strategy at the regional level suggests a new response to the problems of un- and semi-skilled workers. Ideally (and unsurprisingly, given that common principles underlie both), the two policies would prove mutually reinforcing.

The un- and semi-skilled fall analytically into two brutally distinct groups. Those in the first group are typically the victims of the corrosive effects of long years of physically demanding, stultifying labor, or of childhoods and educations that make it all but impossible to acquire the basic skills required to master the more advanced ones. Those in the second group have typically suffered a milder form of the same injuries that felled those in the first, or simply resisted adversity better. We take it for granted that society will find it politically expedient if not morally obligatory to guarantee the (decent?) subsistence of the first group. We also take it for granted that almost all interested parties-the firms, taxpaying citizens, political groups-have convergent interests in seeing as many members of the second group as possible enter the high-skill economy rather than become wards of the state in the first.

The difficulty, of course, is that it is often impossible to say for sure who among the un- and semi-skilled is in which group. For one thing, the ability to enter the high-skill economy depends on the latter's size, which itself depends in part on the availability of skilled labor. For another, it is often difficult to know whether some combination of remedial training and interim support will not allow persons previously treated as marginally employable to learn to teach themselves. In the virtuous circle, improved training and welfare programs equip many of these once assigned to the first group to find skilled work, which is available-in 
part, but only in part--because employers expect the new programs to provide the skill reserves they require. In the vicious circle, the failure of faulty programs of remediation produces contrary expectations, and the resulting reduction of job offerings pushes some members of the second group back into the first.

The trade unions, we believe, can encourage the formation of virtuous circles by pursuing strategies which would be direct extensions of their efforts to organize open labor markets and regional economies. The structuring principle is to encourage the horizontal connection among local actors in a way which makes the labor movement an integral piece of the resulting system: the networking discussed in the preceding section. One way to see how this might occur is to examine briefly the changing pattern of welfare provision in the Federal Republic; a second is to survey more precisely than before how changes in the unions themselves can be related to problems of industrial restructuring at the local level.

In the Federal Republic, as in many other advanced industrial economies, the provision of welfare services is a task managed in "the local political arena." 28 The central state has reduced its support of both the social insurance and training systems, partly as a result of fiscal pressure (budget "consolidations"), and partly for political or ideological reasons (attacks on the "exaggerations" of the welfare state). Under these conditions, local administrative units-the Gemeinden or communes-have been forced to assume final responsibility for meeting the minimal needs of the increasing fraction of the unemployed which falls through the tattered social-security net. Correspondingly, the share of the total number of communal welfare recipients who are unemployed has been rising, and in several West German cities now exceeds 25 percent ${ }^{29}$ However much the Gemeinden may have once tried to evade this responsibility, they increasingly recognize it openly in an effort to maintain social peace or-in the large cities under Social Democratic control-improve their political situation.

What is crucial from our perspective is that the assumption of responsibility is accompanied by the growing conviction that the utility of social services, not least those addressed to the un- and semi-skilled whose jobs are most at risk, depends on the way they are connected with each other. There is a tendency "at the local level to look for new (horizontal) organizational forms in order to improve the effectiveness of the social-welfare administration and the services which it offers to combat mass and long-term unemployment." ${ }^{130}$ Indeed if needs bundle in the sense that those without jobs are also likely to have housing, family and medical problems and if potential welfare recipients are incompletely informed about their eligibility for benefits then "horizontal" organizations combining services into the bundles needed by particular persons are a precondition for an acceptably efficient and equitable welfare system. ${ }^{31}$ To see why, simply imagine two persons who need and have the right to the same ten 
services, although neither is perfectly informed of his or her entitlements. Imagine further that if any one element of the bundle is missing, the others are useless: it is hard to get a job without a home, and hard to maintain a home without a job. Without "horizontal" coordination-in the person, say, of a welfare worker aware of the connection among the elements of the bundle and the situation of both recipients - each will, as is now often the case, receive a different five, with the result that neither is helped and each is envious of what the other has.

This brings us back to familiar terrain. The more active the union is in constructing an exoskeleton which protects the currently employed or the temporarily unemployed against the dangers of long-term unemployment, the easier it becomes to imagine and construct the kinds of programs necessary to move the (potentially) long-term unemployed into the high-skill economy. Plainly, comprehensive strategies are required which overcome the divisions traditional in the Federal Republic (and elsewhere) between measures to create jobs, combat youth unemployment, provide specific social services, and the like. ${ }^{32}$ Instead of offering material compensation or short-term remediation, these comprehensive programs should increase the recipients' capacity for autonomous action by improving their living, learning, and working conditions. Presumably, increased control over open labor markets requires the same.

An analogous tendency toward the articulation of comprehensive programs and the creation of the institutions necessary to operate them can be seen in the evolution of the unions' "occupation plans" (Beschäftigungspläne). These are typically agreements between a union-usually via the factory council-and firms on the verge of closing plants or laying off large numbers of employees. In 1987 and 1988 there were 20 such agreements, above all in the steel and shipbuilding industries. Their goal is captured in the union slogan, "better training than layoffs." They are financed by a combination of funds which would normally be required for individual severance payments and subsidies from the Federal Department of Labor (Bundesanstalt für Arbeit), as well as federal programs for regional development. They are explicitly intended to provide "preventive training" to employees who are "threatened by unemployment, and once unemployed, would be difficult to attract to further training measures." 33

Surveys of the operation of these plans reveals an ambiguous result. ${ }^{34}$ Typically the Beschäftigungspläne are concluded in the midst of a crisis, when room for manoeuver is already substantially reduced. Hence the chances of identifying and realizing innovative solutions-new products or processes-are slim. The plans, in short, are usually more palliative than preventive, and that obviously limits and redirects their effect. At the same time, despite this limitation, the plans and the activities they encourage have often revealed an innovative potential in the firms which would otherwise have gone undetected. 
Not least, employees who took advantage of the training possibilities offered by the plans in many cases succeeded in finding more skilled jobs in other firms.

There are signs in the latest rounds of collective bargaining that these developments are just the first steps of a union effort to press the firms to develop "preventive" training and personal management schemes which would simultaneously protect the un- and semi-skilled and create the possibility of better coordinating employment with social-welfare policy. An example, mentioned earlier, is the April 1987 agreement between IG Metall and Volkswagen. The agreement gives the factory councilors comprehensive rights of consultation in the introduction of new technologies and organizational systems in individual plants. The area of compulsory consultation includes personnel planning and assessment of training needs. On the basis of this contract, for example, the thorough reorganization of one parts-production area included a "700-hour program" of highly systematic training. A quota system gave preferential treatment to applications from un- and semi-skilled workers, and their participation was, by the standards of such programs, disproportionately high. In this connection the LGRTV I, also mentioned earlier, is equally significant. This contract provides for the creation of bipartite, continuing-education commissions in the plants. IG Metall would like to use these to ensure that groups such as low-paid women, foreign workers, and all those threatened by layoffs receive preferential treatment in continuing-education programs.

In isolated cases, moreover, particularly active factory councilors have begun to extend the modernization pacts discussed earlier in a way which one of their number described as a "reversal of managerial thinking." These activists are pursuing a double goal. On the one hand they are trying to secure their firm's future by insisting on investments in the development of new, more diversified products. On the other, they insist on meeting what they see as a collective responsibility for the protection of the un- and semi-skilled by offering special training programs directed to the latter's needs, rather than simply substituting them with more skilled workers drawn from the external labor market. The benefits of forced-draft, concerted reorganization are intended, in these plans, to produce the supplemental revenues needed to finance the extended training programs. Projects such as these seem to us to embody the connection between active participation in restructuring and protection, even extension of employee rights-here of the un- and semi-skilled-which could become the defining feature of a new overall trade-union strategy.

\section{TOWARD A NEW DIVISION OF LABOR IN THE LABOR MOVEMENT}

The two conclusions of our argument-the need for a decentralizing relocalization of each union combined with an opening to new groups, including 
the other unions-are not meant to suggest that the revitalization of the local labor movement could replace the national one. A renewal of local structures, we believe, is possible only on the condition that the national ones are renewed well. To begin with, the national unions must do their best to assure that the local unions have the resources and competence necessary to minimize the risks of restructuring for employees and maximize the opportunities. This means, for example, that the unions on the national level must use every occasion to extend local codetermination. This requires support whenever possible for factory councils but also, for example, for the social movements which aim to make the local welfare state more equitable and efficient, as well as for ecology groups which monitor the regional environment. Only the national trade-union entities can organize the exchanges of information and provide the consulting services without which extension of local labor participation cannot succeed.

Just as important, only the national labor movement can, through its legislative influence, help create a system of incentives which encourages the formation and expansion of flexible, high-skill, and hence robust regional economies. So too is national legislation required to shape the development of the local welfare systems which these regional economies require. The stakes here are enormous. A few islands of flexible prosperity will always be threatened by a sea of potential social discontent. But the more numerous and extensive the regional economies, the greater the probability that un- and semi-skilled workers will be able to find places within them through continuing education. The more numerous and extensive the regional economies, the easier it becomes to create national-or state-level-reinsurance systems which facilitate the restructuring of crisis regions by means of subsidies from the prosperous ones.

How exactly the division of labor between local and national union instances will develop- what, for example, is best regulated by a central, uniform rule, and what is best left to the discretion of the local labor movement-will be decided in practice. The division of responsibility between the center and the local unions in the old system was, after all, nothing fixed. Rather, it was the result of an endless series of contentious, more or less democratic compromises to shifting conditions Such compromises were possible because all parts of the labor movement came, through their many conflicts with management, to an understanding of their situation and their goals which all could share.

Today the task is to renew through conflict and discussion common understanding. If we have currently grasped the current logic of industrial reorganization, then the labor movement will come to such an understanding only when it is has succeeded in linking the movement to make production more flexible with a movement to make the reintegration of conception and execution, and life and work on which such flexibility depends the occasion for a redefinition of democracy. 


\section{NOTES}

1. See generally, Volker R.Berghahn, and Detlev Karsten, Industrial Relations in West Germany (Oxford: Berg Publishers, 1987). Notice also that the German programs of vocational training are also often referred to as a dual system in that they combine classroom and shop learning.

2. Martin Baethge and Herbert Oberbeck, "Service Society and Trade Unions," in The Service Industries Journal, no. 8 (1988): 389-391.

3. Birgit Mahnkopf, "Gewerkschaftspolitik und Weiterbildung. Chancen und Risiken einer qualifikationsorientierten Modernisierung gewerkschaftlicher (Tarif)Politik." Discussion paper, WZB, October, 1989, p. 5.

4. For a precis of our views on this topic and for additional references to the relevant literature, see Horst Kern and Charles F. Sabel, "Gewerkschaften im ProzeB der industriellen Reorganisation. Eine Studie strategischer Problem," Gewerkschaftliche Monatshefte, no. 10 (1989): 602-619; Charles F. Sabel, Horst Kern, and Gary Herrigel, "Collaborative Manufacturing: New Supplier Relations in the Automotive Industry and the Redefinition of the Industrial Corporation," paper for the International Motor Vehicle Program, M.I.T., Cambridge, MA , March 31, 1989. A German translation is published in Zulieferer im Netz-Zwischen Abhängigkeit und Partnerschaft, Hans Gerhard Mendius, and Ulrike Wendeling-Schröder, eds. (Cologne: Bund-Verlag, 1991), pp. 203-227.

5. Note, however, that in Japan the major automobile producers increasingly delegate production of low- or medium-volume specialty vehicles to "contract assemblers" who may have played an important role in designing some component of the car.

6. Reinhard Doleschal, "Just-in-time Strategien und Betriebspolitik im Automobilsektor" in Just-in-time Konzepte und Betriebspolitik, Hans-Böckler Stiftung, Graue Reihe -new series, Reinhard Doleschal and Arno Klönne, eds., n. 16, Düsseldorf, 1989b, p. 8ff.

7. Charles F. Sabel, "Flexible Specialization and the Re-Emergence of Regional Economies," in Reversing Industrial Decline?, Paul Hirst and Jonathan Zeitlin, eds. (Oxford: Berg Publishers, 1989); see also Dieter Läpple, "Trendbruch in der Raumentwicklung. Auf dem Weg zu einem neuen industriellen Entwicklungstyp," Informationen zur Raumentwicklung, no. 11/12 (1986): 918, and Dieter Läpple, "Neue Technologien in räumlicher Perspektive," Informationen zur Raumentwicklung, no. 4 (1989): 225.

8. There is no doubt that the suppliers, large and small, understand what is at stake. Lured by the prospect of expansion or driven by the fear of exclusion, West German auto parts suppliers have begun to invest at a frantic rate. Between 1978 and 1986 West German producers of cars and trucks increased their total annual investments by 134 percent, while parts suppliers in the industry increased their investment by 162 percent. The increases in investment in this period measured per employee were, respectively, 109 percent and 124 percent. Richard Doleschal, "Die Automobil-Zulieferindustrie im Umbruch," working paper, Lukács Institut für Sozialwissenschaften, e.V., Universität GHS Paderborn, Paderbom, 1989, pp. 27-29.

9. A recent study of the West German trade union reached opposite conclusions regarding the behavior of "modern" employees-those directly involved with the technological and organizational innovations under discussion. It claims that far from turning their backs on the unions, such employees may well become one of their most reliable bases of support. This conclusion, we believe, rests on a statistical artifact. In the study's sample of firms, workers in "modern" companies are more likely to belong to unions than workers in firms where there has been little experimentation with the new methods. Hence the assertion of an affinity between "modern" workers and unions. Because many of the most advanced firms in West Germany are among the most 
unionized, it is hard to imagine - in the short run, at least-any other outcome. But a comparison of the union membership rates of "modern" workers as against traditional workers within "modern" companies would, we are confident, reveal a different, indeed contrary, result - and one which better indicates the trend of developments. See Walter Bertl, Reinhard Rudat, and Reinhard Schneider, Arbeitnehmerbewußein im Wandel. Folgerungen für Gesellschaft und Ge9werkschaft, (Frankfurt: Main, 1989), p. 63; and Dieter Fröhlich, Hubert Krieger, Reinhard Rudat, and Reinhard Schneider, Gewerkschaften vor den Herausforderungen der Neunziger Jahre, (Frankfurt: Main, 1989).

10. Michael Schwartz, "Beratungsgruppen für den Betriebsrat-zur Nachahmung empfohlen," Die Mitbestimmung, no. 8 (1989): 448-449.

11. This is probably the most robust funding of methodologically sophisticated studies of the social psychology of work. See Melvin L. Kohn, "Unresolved Issues in the Relationship between Work and Personality," in The Nature of Work: Sociological Perspectives, Kai Erikson, and Steven Peter Vallas, eds. (New Haven: American Sociological Association and Yale University Press, 1990), pp. 36-86, esp. pp. 40-41.

12. Hartwig Heine, and Rüdiger Mautz, Industriearbeiter contra Umweltschutz? (Frankfurt: Main, 1989).

13. Birgit Mahnkopf, "Gewerkschaftspolitik und Weiterbildung," p. 22.

14. Ibid., p. 23.

15. Martin Baethge, Rolf Dobischat, Rudolf Husemann, Antonius Lipsmeier, Christiane Schiersmann, and Doris Wedding, Gutachten über Forschungsstand und Forschungsdefizite im Bereich betrieblicher Weiterbildung unter besonderer Berücksichtigung der Belange der Mitarbeiter und darauf aufbauend Erarbeitung einer zukunftsweisenden Forschungskonzeption, Göttingen and Bonn, unpublished manuscript, 1989, p. 81.

16. Martin Baethge, et al., Gutachten über Forschungsstand und Forshungsdefizite im Bereich betrieblicher Weiterbildung, p. 81.

17. Ibid., p. 422-427.

18. Ibid., p. 422.

19. Birgit Mahnkopf, "Gewerkschaftspolitik und Weiterbildung," pp. 41-43, and Baethge, Martin, et al., Gutachten über Forschungsstand und Forschungsdefizite im Bereich betrieblicher Weiterbildung, pp. 450-453.

20. Michael Schwartz, "Beratungsgruppen für den Betriebsrat," p. 448.

21. For an interesting example, see Ursula Richter and Manfred Zitzelsberger, "Vom Tornado in die Umwelttechnik," Die Mitbestimmung, no. 12 (1989): 74.

22. Oskar Negt, Christine Morgenroth, Heiko Geiling, and Edzard Niemeyer, Emanzipationsinteressen und Organizationsphantasie. Eine ungenutzte Wirklichkeit der Gerwerschaften? Zur Erweiterung sozialkultureller Handlungsfelder am Beispeil der DGB-Ortskartelle (Cologne: Bund-Verlag, 1989), p. 188.

23. See Oskar Negt, et al., Emanzipationsinteressen und Organizationsphantasie. esp. p. 184; Wilhelm Adamy and Gerhard Bosch, "Gerwerkschaften in der Region-Impulsgeber oder Dulder regionaler Beschäftigunspolitik," in Lokale Beschäftigungspolitik, Hans E. Meier and Hellmut Wollman, eds., in Stadtforschung aktuell, v. 10, Basel, 1986, p. 502 ff.; Jürgen Hoffman and Dieter Läpple, "Kristallisationspunkte regionaler Gestaltungspolitik," Die Mitbestimung, no. 12 (1989): 692-694; Arnim von Gleich, "Von der Konjunktur zur Struktur," Die Mitbestimmung, no. 2 (1989): 688-689; and also Eckhart Hildebrandt, "Zwischen Bestandssicherung und Gestaltung," Die Mitbestimmung, no. 7 (1989): 369; Hellmut Wollmann, "Stadtpolitik-Erosion oder Erneuerung des Sozialstaats, von unten?" "Die zweiter Stadt," Bernhard Blanke, et al., 
eds. in Leviathan, special number, no. 7 (1986); Lutz Hoffmann, Uwe Neumann, Interessenvertretung im Klein-und Mittlelbetrieb. Eine empirische Untersuchung über Bedingungen und Prozesse kollektiver Gegenmacht. Unpublished Ph.D. thesis, Fachbereich Sozialwissenschaften, Universität Göttingen, 1987, p. 535.

24. Oskar Negt, et al., Emanzipationsinteressen und Organisationsphantasie, p. 185.

25. Ibid., esp. p. 184.

26. See Lutz Hoffmann and Uwe Neumann, Intersessenvertretung im Klein- und Mittelbetrieb, p. 540; Oskar Negt, et al., Emanzipationsinteressen und Organisationsphantasie, p. 186; Jürgen Hoffman and Dieter Läpple, "Kristallisationspunkte regionaler Gestaltungspolitik," p. 694.

27. Compare the insightful overview in Wilhelm Adamy and Gerhard Bosch, "Gewerkschaften in der Region," p. 502.

28. Hellmut Wollmann, "Stadtpolitik," pp. 79-101.

29. Ibid., p. 85.

30. Ibid., p. 87.

31. To streamline the argument we omit consideration of voucher systems, in which the welfare recipients do all the "coordinating" of programs without need of any administrative assistance. Note, however, that such systems also depend on implausible assumptions about perfect information.

32. Benny Hjern, "The Swedish Social Welfare Municipality," in International Review of Comparative Public Policy, vol. 2, Nicholar Mecuro, and Douglas E. Ashford, eds. (Greenwich: JAI Press, 1990), pp. 85-107.

33. Birgit Mahnkopf, "Gerwerkschaftspolitik und Weiterbildung," p. 35.

34. Gerhard Bosch, "Beschäftigungspläne in der Praxis," WSI-Mitteilungen, no. 4, (1989): 197-206.

Politics \& Society 19, no.4 (1991): 373-402. 